J Jpn. J. Hosp. Pharm.

$\left[\begin{array}{cc}\text { 瓷 } \\ 20 \text { (2) } 139-148 \text { (1994) }\end{array}\right.$

\title{
メロペネム注射剂の各種輸液・楽剤との配合变化試験
}

濱詰ゆかり，藤井聖子，野口哲男

住友製薬総合研究所製剤技術研究所†

\section{Compatibility Test of Meropenem Injection with Various Infusions and Injections}

\author{
YukaRi Hamazume, KiYoko FujiI, Tetsuo Noguchi \\ Formulation Research Laboratories, Sumitomo Pharmaceuticals Research Center $\dagger$
}

(Received November 2, 1993

(Accepted December 20, 1993)

Compatibility of meropenem injection, a novel carbapenem antibiotic, was studied with 34 infusions and 107 injections dissolved mainly in saline. These results suggest that proper reconstitution method of meropenem injection has been established.

Keywords_-meropenem, injection, carbapenem, antibiotic, infusion, compatibility

緒言

メロペネム（図 1) はグラム陽性菌およびグラ ム陰性菌の広い範囲にわたって優れた抗菌活性を 示す新規カルバペネム系抗生物質であり，種々の 感染症に対する効能・効果が認められている1).

メロペネム注射剂は各種輸夜・薬剤との配合が 予想される. 一方，同じカルバペネム系抗生物質 であるイミペネム注射剤は乳酸塩を含む輸液とは 配合禁忌であり 2)，メロペネム注射剤についても 臨床の場での適切な配合法に関する情報が必要と 考えられた。今回, 本剤と各種輸夜 (34種), 生理 食塩液中での各種薬剤 (107種) との配合を検討し たので報告する，配合輸液・薬剤は現在病院で汎 用されている製品を選択した。

† 大阪府荻木市蔵垣内1-3-45; 1-3-45, Kurakakiuchi， Ibaraki-shi, Osaka, 567 Japan

\section{実験材料および方法}

\section{1. 試料調製}

1）各種輸液との配合

メロペネム注射剂 $0.5 \mathrm{~g}$ 力価 (Lot No. P-031) 1バイアルを市販の各種輸液（表 1) に配合し, 試料とした。 ただし，アミカリック（テルモ）以 外の高カロリー輸液はその添付文書に従い, アミ ノ酸製剂を添加したのちメロペネム注射剂を配合 した.

2）各種薬剤との配合

薬剤（1 種，表 $2 \sim 4$ ）を生理食塩液 $100 \mathrm{ml}$ に 配合した溶液にメロペネム注射剂 $0.5 \mathrm{~g}$ 力価 (Lot No. P-031） 1 バイアルを配合し，試料とした. また, 点滴静注用の薬剤でその容量が $50 \mathrm{ml}$ 以上 であり，一般に希釈せずに用いる薬剤について は，その薬剤にメロペネム注射剂 $0.5 \mathrm{~g} 1$ バイア ルを直接配合し，試料とした。 
<smiles>C[C@@H](O)[C@H]1C(=O)N2C(C(=O)O)=C(S[C@H]3CN[C@@H](C(=O)N(C)C)C3)[C@H](C)[C@H]12</smiles>

$3 \mathrm{H}_{2} \mathrm{O}$

図 1. メロペネムの構造

1)，2）とも，配合した液は室温 $\left(25 \pm 2^{\circ} \mathrm{C}\right)$ 飞 放置した。

\section{2. 測定}

1）外観変化

配合直後，3 時間後， 6 時間後，および24時間 後に肉眼的に観察した.

\section{2) $\mathrm{pH}$}

堀場製 $\mathrm{pH}$ メーター F-8AT 型を用い, 配合 直後， 3 時間後， 6 時間後，および 24 時間後に測 定した。

\section{3）メロペネムの残存力価}

試料を $0.5 \mathrm{mg}$ 力価 $/ \mathrm{ml}$ の濃度になるようにト リエチルアミンーリン酸緩衝液 $(\mathrm{pH}$ 5.0) で希䣋 し, HPLC 絶対検量線法 ${ }^{3)}$ により測定し, 配合直 後の力価を $100 \%$ として残存率を算出した. HPLC システムは島津製 LC-10A を用いた。検出波長 はメロペネムの $\lambda_{\max }$ である $300 \mathrm{~nm}$, 移動相は卜 リエチルアミンーリン酸緩衝液 ( $\mathrm{pH} \mathrm{5.0)}$ ：メタ ノール $=5: 1$, カラムは Sumipax ODS A-212 $(6 \mathrm{~mm} \phi \times 15 \mathrm{~cm}, 5 \mu \mathrm{m})$, 流速は $1 \mathrm{ml} / \mathrm{min}$ の条件 で行った.

\section{結果および考察}

\section{1. 各種輸液との配合}

測定結果を表 $5 ， 6$ に示す.

(1) 外観

すべての輸液において結晶析出, 濁りおよび沈

表 1. 本試験に用いた輸液

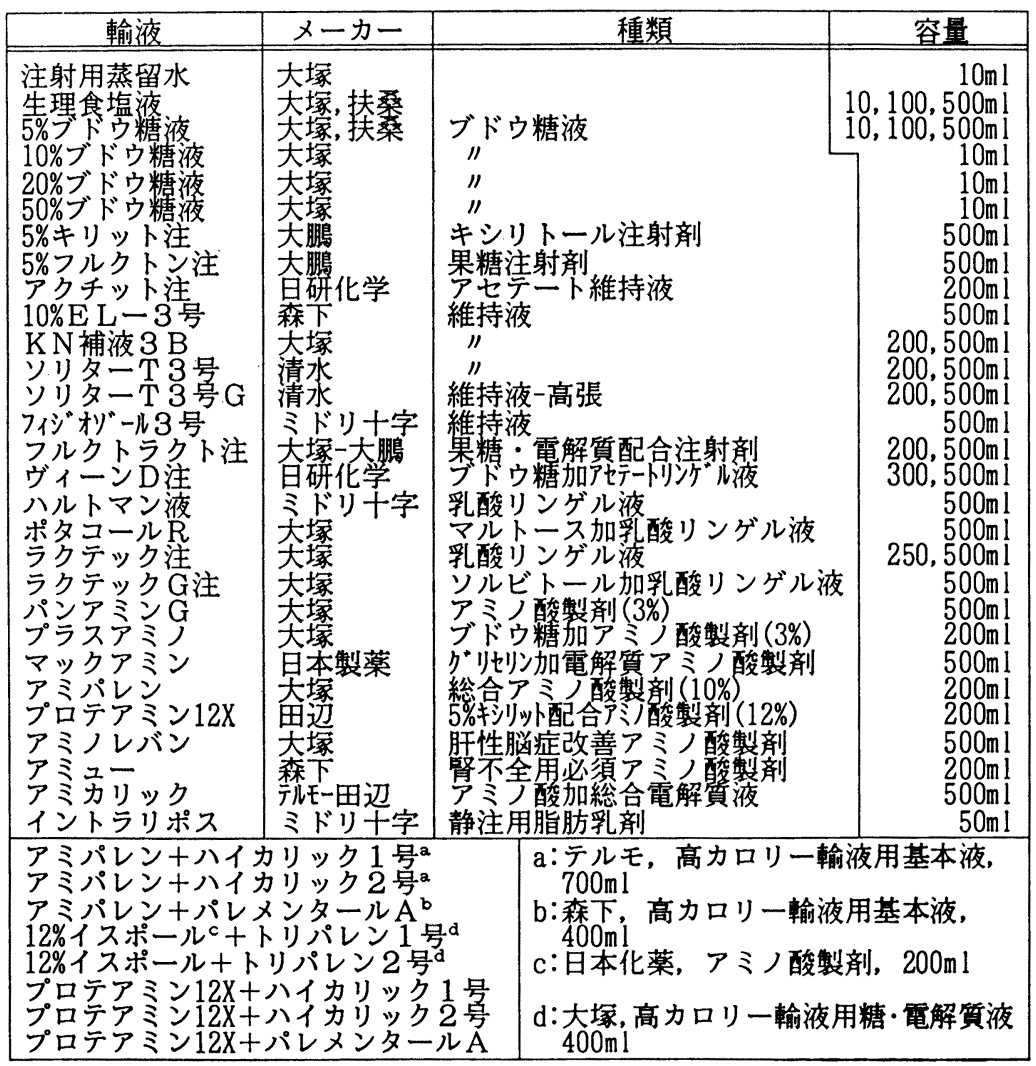


表 2. 本試験に用いた薬㶡 (1)

\begin{tabular}{|c|c|c|c|}
\hline & 薬剂名 & メーカー & 配合量 \\
\hline 剂 & 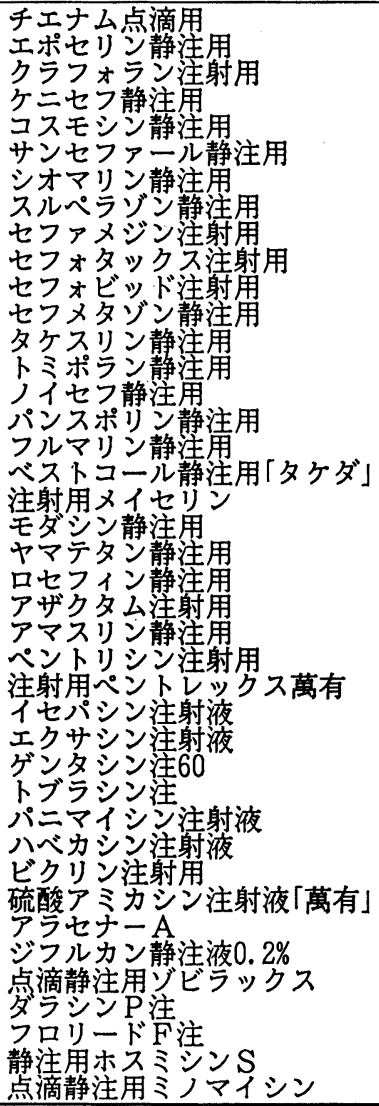 & 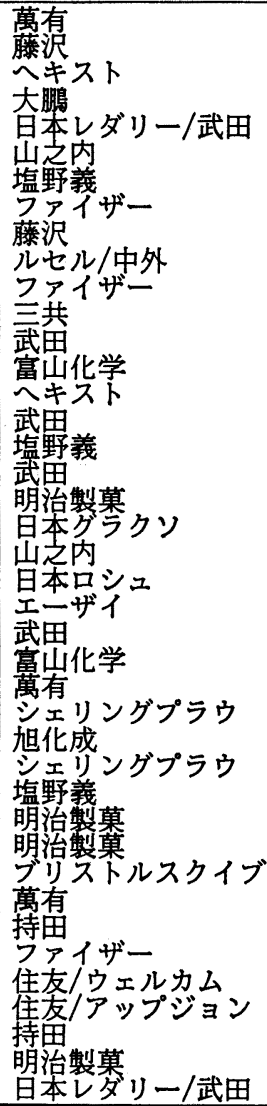 & $\begin{array}{r}500 \mathrm{mg} \\
1 \mathrm{~g} \\
1 \mathrm{~g} \\
1 \mathrm{~g} \\
1 \mathrm{~g} \\
1 \mathrm{~g} \\
1 \mathrm{~g} \\
1 \mathrm{~g} \\
1 \mathrm{~g} \\
2 \mathrm{~g} \\
1 \mathrm{~g} \\
2 \mathrm{~g} \\
1 \mathrm{~g} \\
1 \mathrm{~g} \\
1 \mathrm{~g} \\
1 \mathrm{~g} \\
1 \mathrm{~g} \\
1 \mathrm{~g} \\
1 \mathrm{~g} \\
1 \mathrm{~g} \\
1 \mathrm{~g} \\
1 \mathrm{~g} \\
1 \mathrm{~g} \\
1 \mathrm{~g} \\
4 \mathrm{~g} \\
2 \mathrm{~g} \\
400 \mathrm{mg} \\
400 \mathrm{mg} \\
120 \mathrm{mg} \\
90 \mathrm{mg} \\
100 \mathrm{mg} \\
100 \mathrm{mg} \\
200 \mathrm{mg} \\
100 \mathrm{mg} \\
300 \mathrm{mg} \\
100 \mathrm{mg} \\
250 \mathrm{mg} \\
600 \mathrm{mg} \\
400 \mathrm{mg} \\
4 \mathrm{~g} \\
100 \mathrm{mg}\end{array}$ \\
\hline
\end{tabular}

澱は観察されず，イントラリポスとの配合以外で 澄明であった。メロペネム自身の水への溶解度は $14 \mathrm{mg} / \mathrm{ml}$ であるが，溶解補助剂である乾燥炭酸 ナトリウムの添加によりメロペネムの溶解性が更 に向上している.

配合時の色調およびその変化は，メロペネムの 濃度および輸液の成分に依存すると考えられる. すなわち，1 バイアルを $100 \mathrm{ml}$ 以上に溶解した 希薄溶液では, 配合初期は無色〜微黄色であり， 24時間後でも無色のままか若干変化する程度であ ったが，その変化の程度は残存力価とは必ずしも 関係せず，例えば，アミノ酸輸液の場合はメロぺ ネムの分解がかなり進んでも無色の場合が多かっ た. 一方, 注射用水, 生理食塩液およびブドウ糖 溶液 $10 \mathrm{ml}$ にメロペネム注射剤 1 バイアルを溶解
した濃厚溶液の場合は, 希薄溶液の場合と比べ, 色調の変化が大きかった.

(2) $\mathrm{pH}$

すべての輸液に打いて $4.7 \sim 8.1$ と臨床使用上問 題ない範囲であった. $\mathrm{pH}$ の著しい変動は認めら れなかったので，表 $5 ， 6$ には配合直後 $(0 \mathrm{~h})$ と 24時間後の値のみ示した.

(3) 残存力価

a . 注射用蒸留水, 生理食塩液

濃度に関わらず，配合後 6 時間目でメロペネム の残存力価が $90 \%$ 以上を示した.

b. 糖液

糖濃度が高くなるほどメロペネムは不安定であ った， $\beta$-ラクタム系抗生物質とブドウ糖との反応 は知られて拈り")，メロペネムの場合もその傾向 
表 3. 本試験に用いた薬剤（2）

\begin{tabular}{|c|c|c|c|}
\hline \multicolumn{2}{|r|}{ 薬剂名 } & メーカー & 配合量 \\
\hline 抗悪性 & 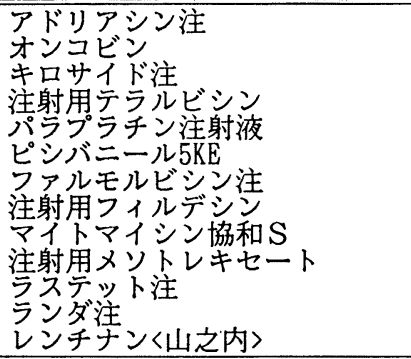 & 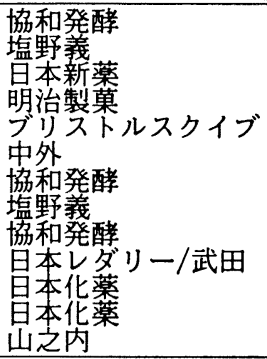 & $\begin{array}{r}10 \mathrm{mg} \\
1 \mathrm{mg} \\
200 \mathrm{mg} \\
20 \mathrm{mg} \\
450 \mathrm{mg} \\
5 \mathrm{KE} \\
10 \mathrm{mg} \\
3 \mathrm{mg} \\
10 \mathrm{mg} \\
50 \mathrm{mg} \\
100 \mathrm{mg} \\
50 \mathrm{mg} \\
1 \mathrm{mg}\end{array}$ \\
\hline 血液系 & 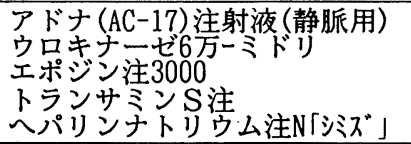 & $\begin{array}{l}\text { 田辺 } \\
\text { 望リ十字 } \\
\text { 中外 } \\
\text { 第立 } \\
\text { 清水/武田 }\end{array}$ & $\begin{array}{l}100 \mathrm{mg} \\
6 \text { 万国際単位 } \\
3000 \text { 国際位 } \\
1 \mathrm{~g} \\
5000 \text { 峃位 }\end{array}$ \\
\hline $\begin{array}{l}\text { 循環器 } \\
\text { 用剂 }\end{array}$ & 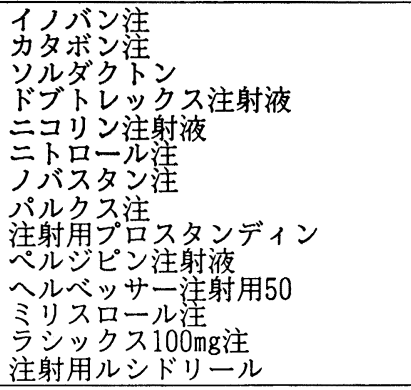 & 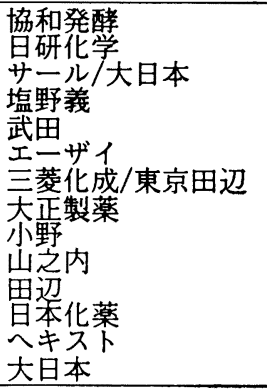 & $\begin{array}{r}100 \mathrm{mg} \\
100 \mathrm{mg} \\
200 \mathrm{mg} \\
100 \mathrm{mg} \\
500 \mathrm{mg} \\
5 \mathrm{mg} \\
10 \mathrm{mg} \\
10 \mu \mathrm{g} \\
500 \mu \mathrm{g} \\
10 \mathrm{mg} \\
50 \mathrm{mg} \\
50 \mathrm{mg} \\
100 \mathrm{mg} \\
750 \mathrm{mg} \\
\end{array}$ \\
\hline $\begin{array}{l}\text { ビタミ } \\
\text { ン剤 }\end{array}$ & 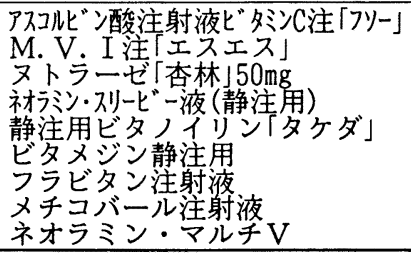 & $\begin{array}{l}\text { 扶桑 } \\
\text { エスス } \\
\text { 查㷊化薬 } \\
\text { 武田 } \\
\text { 共 } \\
\text { ト-フ体/山之内 } \\
\text { エーザイ } \\
\text { 日本化薬 }\end{array}$ & $\begin{array}{r}500 \mathrm{mg} \\
5 \mathrm{ml} \\
50 \mathrm{mg} \\
10 \mathrm{ml} \\
1 \Lambda^{*} 1 乃^{\prime} \mu \\
1 \Lambda^{*} 1 乃^{\prime} \\
20 \mathrm{mg} \\
500 \mu \mathrm{g} \\
10 \mathrm{ml}\end{array}$ \\
\hline
\end{tabular}

表 4. 本試験に用いた薬剤（3）

\begin{tabular}{|c|c|c|c|}
\hline \multicolumn{2}{|r|}{ 薬剂名 } & メーカー & 配合量 \\
\hline 㴮华器 & $\begin{array}{l}\text { ガスター注射用 } \\
\text { キャベジンU゙ーワ } \\
\text { ザンタック注射液 } \\
\text { ソルコセリ少」注」 } \\
\text { タガメット注射液 } \\
\text { プリンペラン注射液 }\end{array}$ & $\begin{array}{l}\text { 山之内 } \\
\text { 興和 } \\
\text { 早本ラクン } \\
\text { 蓤/大鵬 } \\
\text { 藤沢 } \\
\text { 淑 }\end{array}$ & $\begin{array}{r}20 \mathrm{mg} \\
400 \mathrm{mg} \\
50 \mathrm{mg} \\
4 \mathrm{ml} \\
200 \mathrm{mg} \\
10 \mathrm{mg} \\
\end{array}$ \\
\hline $\begin{array}{l}\text { 副腎皮質 } \\
\text { 机済 }\end{array}$ & 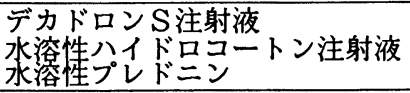 & $\begin{array}{l}\text { 萬有 } \\
\text { 萬有 } \\
\text { 壏野義 }\end{array}$ & $\begin{array}{r}100 \mathrm{mg} \\
500 \mathrm{mg} \\
50 \mathrm{mg} \\
\end{array}$ \\
\hline $\begin{array}{l}\text { 代謝系 } \\
\text { 用剂 }\end{array}$ & 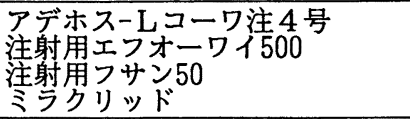 & 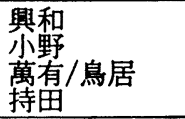 & $\begin{array}{c}40 \mathrm{mg} \\
500 \mathrm{mg} \\
50 \mathrm{mg} \\
25000 \text { 単位 }\end{array}$ \\
\hline $\begin{array}{l}\text { 血槳分 } \\
\text { 画製剂 }\end{array}$ & $\begin{array}{l}\text { ヴェノグロブリン-I } \\
\text { ヴェノグロブリン-IH } \\
\text { ガンマ・ベニン } \\
\text { ベニロン } \\
\text { ポリグロビンN }\end{array}$ & $\begin{array}{l}\text { ミドリ十字 } \\
\text { ドリ†字 } \\
\text { ヘキスト } \\
\text { 化血研/帝人 } \\
\text { バイエル }\end{array}$ & $\begin{array}{l}2.5 \mathrm{~g} \\
2.5 \mathrm{~g} \\
2.5 \mathrm{~g} \\
2.5 \mathrm{~g} \\
2.5 \mathrm{~g}\end{array}$ \\
\hline その他 & 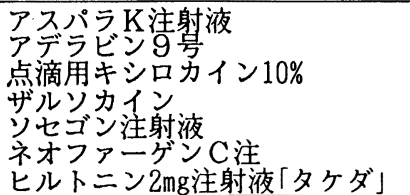 & $\begin{array}{l}\text { 田啝化学 } \\
\text { 藤沢 } \\
\text { 㞥淮内 } \\
\text { 大鵬 } \\
\text { 武田 }\end{array}$ & $\begin{array}{r}10 \mathrm{ml} \\
2 \mathrm{ml} \\
10 \mathrm{ml} \\
10 \mathrm{ml} \\
30 \mathrm{mg} \\
20 \mathrm{ml} \\
2 \mathrm{mg}\end{array}$ \\
\hline
\end{tabular}


表 5. ×ロペネム注射剤 $0.5 \mathrm{~g}$ と輸夜との配合変化 (1)

\begin{tabular}{|c|c|c|c|c|c|c|c|c|c|c|c|c|c|}
\hline \multirow{2}{*}{ 輸液名 } & \multirow{2}{*}{ 容量 } & \multicolumn{5}{|c|}{ メロペネム残存力価（\%) } & \multicolumn{5}{|c|}{ 外観 } & \multicolumn{2}{|c|}{$\mathrm{pH}$} \\
\hline & & $\mathrm{Ohr}$ & $1 \mathrm{hr}$ & $3 \mathrm{hr}$ & $6 \mathrm{hr}$ & $24 \mathrm{hr}$ & Ohr & $1 \mathrm{hr}$ & $3 \mathrm{hr}$ & $6 \mathrm{hr}$ & $24 \mathrm{hr}$ & $\mathrm{Ohr}$ & $24 \mathrm{hr}$ \\
\hline 注射用蒸留水 & $0 \mathrm{ml}$ & 100 & 97.7 & 96.9 & 92.0 & 70.8 & 無色 & 微黄 & & $\leftarrow$ & 黄色 & 7.90 & \\
\hline \multirow[t]{3}{*}{ 生理食塩水 } & & 00 & 3.5 & 3.6 & 0.5 & 1.9 & 無色 & 微黄 & & $\leftarrow$ & 黄色 & 7.82 & \\
\hline & $100 \mathrm{ml}$ & 00 & .9 & 9.2 & 98.2 & 2.4 & 無色 & $\leftarrow$ & & $\leftarrow$ & $\leftarrow$ & 7.93 & 7.81 \\
\hline & $500 \mathrm{ml}$ & 00 & 3.9 & 7.3 & 97.0 & 90.3 & 無色 & $\leftarrow$ & & $\leftarrow$ & $\leftarrow$ & 7.89 & 7.75 \\
\hline \multirow[t]{3}{*}{ 5\%ブドウ糖液 } & $10 \mathrm{ml}$ & 100 & 1.3 & 85.6 & 75.7 & 8.2 & 無色 & 微黄 & 黄色 & $\leftarrow$ & 濃黄 & 7.89 & 7.60 \\
\hline & $100 \mathrm{ml}$ & 100 & 6.4 & 91.5 & 84.9 & 9.5 & 無色 & $\leftarrow$ & $\leftarrow$ & $\leftarrow$ & 黄色 & 7.95 & 7.96 \\
\hline & $500 \mathrm{ml}$ & 100 & .9 & 90.6 & 83.5 & 3.9 & 無色 & $\leftarrow$ & & $\leftarrow$ & $\leftarrow$ & 7.99 & 7.75 \\
\hline 10\%ブドウ糖液 & $10 \mathrm{ml}$ & 100 & 4.2 & 78.5 & 66.7 & 35.4 & 無色 & 微黄 & $\leftarrow$ & 黄色 & 濃黄 & 7.88 & 7.63 \\
\hline 102 & $\mathrm{~m} \mathrm{~mL}$ & 00 & 7.1 & 71.2 & 51.7 & 20.9 & 無色 & 微黄 & $\leftarrow$ & $\leftarrow$ & 褐色 & 7.82 & 7.58 \\
\hline 50\%ブド & $10 \mathrm{ml}$ & 100 & 7.8 & 55.6 & 37.2 & 5.8 & 微黄 & 黄色 & 褐色 & $\leftarrow$ & $\leftarrow$ & 7.61 & 7.40 \\
\hline $5 \%$ キリット & $0 \mathrm{ml}$ & 00 & 98.7 & 94.3 & 89.1 & 66.3 & 無色 & $\leftarrow$ & $\leftarrow$ & $\leftarrow$ & 微黄 & 8.12 & 7.95 \\
\hline 5\%フルクトン注 & $0 \mathrm{ml}$ & 100 & 3.9 & 90.2 & 86.8 & 71.3 & 無色 & $\leftarrow$ & & $\leftarrow$ & 微黄 & 7.90 & 7.82 \\
\hline アクチット注 & Oml & 100 & 7.9 & 95.2 & 92.8 & 83.6 & 無色 & $\leftarrow$ & $\leftarrow$ & & 微黄 & 6.57 & 6.58 \\
\hline $10 \% \mathrm{EL}-3$ 号 & $0 \mathrm{ml}$ & 100 & 0.3 & 94.0 & 93.3 & 84.5 & 無色 & $\leftarrow$ & & & $\leftarrow$ & 6.16 & 6.14 \\
\hline \multirow[t]{2}{*}{ KN補液3 B } & $200 \mathrm{ml}$ & 100 & 98.2 & 92.6 & 84.2 & 55.6 & 微黄 & $\leftarrow$ & $\leftarrow$ & $\leftarrow$ & 黄色 & 7.75 & 7.78 \\
\hline & Oml & 100 & .9 & 94.1 & 90.6 & 70.7 & 微黄 & $\leftarrow$ & & & 黄色 & 7.59 & 7.51 \\
\hline \multirow[t]{2}{*}{ ソリターT 3号 } & $200 \mathrm{ml}$ & 100 & 95.9 & 90.5 & 84.7 & 47.1 & 微黄 & $\leftarrow$ & $\leftarrow$ & $\leftarrow$ & 黄色 & 7.64 & 7.70 \\
\hline & $500 \mathrm{ml}$ & 100 & 96.9 & 92.7 & 88.0 & 63.7 & 無色 & $\leftarrow$ & $\leftarrow$ & $\leftarrow$ & $\leftarrow$ & 7.44 & 7.34 \\
\hline \multirow[t]{2}{*}{ ソリターT 3号G } & $200 \mathrm{ml}$ & 100 & 94.3 & 85.6 & 74.9 & 34.7 & 微黄 & $\leftarrow$ & $\leftarrow$ & $\leftarrow$ & 黄色 & 7.64 & 7.63 \\
\hline & $500 \mathrm{ml}$ & 100 & 96.4 & 90.2 & 82.5 & 53.0 & 無色 & $\leftarrow$ & $\leftarrow$ & & $\leftarrow$ & 7.28 & 7.15 \\
\hline 7隹㠺゙ール号 & $500 \mathrm{ml}$ & 100 & 98.9 & 97.6 & 95.2 & 84.8 & 無色 & $\leftarrow$ & $\leftarrow$ & $\leftarrow$ & $\leftarrow$ & 5.99 & 6.05 \\
\hline \multirow[t]{2}{*}{ フルクトラクト注 } & $200 \mathrm{ml}$ & 100 & 97.9 & 91.7 & 87.5 & 65.3 & 微黄 & $\leftarrow$ & $\leftarrow$ & $\leftarrow$ & 黄色 & 7.33 & 7.43 \\
\hline & $500 \mathrm{ml}$ & 100 & 98.7 & 96.1 & 92.4 & 75.1 & 無色 & $\leftarrow$ & $\leftarrow$ & $\leftarrow$ & $\leftarrow$ & 6.61 & 6.75 \\
\hline \multirow[t]{2}{*}{ ヴィーンD注 } & $300 \mathrm{ml}$ & 100 & 97.4 & 93.7 & 91.0 & 78.1 & 無色 & $\leftarrow$ & 微黄 & $\leftarrow$ & 黄色 & 6.60 & 6.54 \\
\hline & $500 \mathrm{ml}$ & 100 & 97.7 & 96.0 & 95.9 & 88.4 & 無色 & $\leftarrow$ & $\leftarrow$ & $\leftarrow$ & 黄色 & 5.92 & 5.92 \\
\hline ハルトマン液 & $500 \mathrm{ml}$ & 100 & 95.5 & 92.4 & 89.5 & 75.4 & 無色 & $\leftarrow$ & $\leftarrow$ & $\leftarrow$ & $\leftarrow$ & 7.93 & 7.78 \\
\hline ポタコールR & $500 \mathrm{ml}$ & 100 & 97.3 & 95.2 & 91.6 & 76.5 & 無色 & $\leftarrow$ & $\leftarrow$ & $\leftarrow$ & $\leftarrow$ & 6.73 & 6.73 \\
\hline \multirow[t]{2}{*}{ ラクテック注 } & $250 \mathrm{ml}$ & 100 & 98.3 & 95.6 & 90.7 & 75.8 & 無色 & $\leftarrow$ & 微黄 & $\leftarrow$ & $\leftarrow$ & 7.85 & 7.71 \\
\hline & $500 \mathrm{ml}$ & 100 & 98.6 & 96.1 & 93.5 & 77.7 & 無色 & $\leftarrow$ & $\leftarrow$ & $\leftarrow$ & $\leftarrow$ & 7.81 & 7.69 \\
\hline ラクテック G注 & $500 \mathrm{ml}$ & 100 & 96.9 & 91.4 & 79.8 & 42.8 & 無色 & $\leftarrow$ & $\leftarrow$ & $\leftarrow$ & $\leftarrow$ & 7.81 & 7.84 \\
\hline グリセオール & $500 \mathrm{ml}$ & 100 & 91.4 & 82.5 & 70.5 & 29.8 & 無色 & $\leftarrow$ & $\leftarrow$ & $\leftarrow$ & $\leftarrow$ & 7.65 & 7.63 \\
\hline イントラリポス & $50 \mathrm{ml}$ & 100 & 98.1 & 97.5 & 93.8 & 80.5 & $* 1$ & $\leftarrow$ & $\leftarrow$ & $\leftarrow$ & $* 2$ & 7.87 & 7.88 \\
\hline
\end{tabular}

があることが示唆された. $5 \%$ ブドウ糖液の場合, 容量 $10 \mathrm{ml}$ ではメロペネムは不安定であるが, 100 $\mathrm{ml}$ 以上であれば配合後 3 時間目で残存力価が 90 \%以上を示した. $5 \%$ キリット注, $5 \%$ フルクト ン注の中でも $5 \%$ ブドウ糖液と同程度の残存力価 を示した。

c. 維持液, リンゲル液

アクチット注, $\mathrm{KN}$ 補液 3B $(500 \mathrm{ml})$, ヴィー ン $\mathrm{D}$ 注, ラクテック注については, 配合後 6 時間
目でメロペネムの残存力価が $90 \%$ 以上を示し, $\mathrm{KN}$ 補液 3B (200ml), ソリタ - T 3 号, フルク トラクト注についても，配合後 3 時間目では $90 \%$ 以上を示した. ブドウ糖を含有するソリターT 3 号 Gについては若干低く，3 時間目で85.6\%であ った.

一般的に $\beta$-ラクタム抗生物質の水溶液中での 安定性は $\mathrm{pH}$ に依存し, 中性付近より酸・アルカ リ側で加水分解されやすい(5)。メロペネム注射剂 
表 6. メロペネム注射剤 $0.5 \mathrm{~g}$ と輸夜との配合変化 $(2)$

\begin{tabular}{|c|c|c|c|c|c|c|c|c|c|c|c|c|c|}
\hline & & \multicolumn{5}{|c|}{ メロペネム残存力価 (\%) } & \multicolumn{5}{|c|}{ 外観 } & \multicolumn{2}{|c|}{$\mathrm{pH}$} \\
\hline 輸液名 & 容量 & Ohr & $\mathrm{lhr}$ & $3 \mathrm{hr}$ & $6 \mathrm{hr}$ & $24 \mathrm{hr}$ & $\mathrm{Ohr}$ & $1 \mathrm{hr}$ & $3 \mathrm{hr}$ & $6 \mathrm{hr}$ & $24 \mathrm{hr}$ & $\mathrm{Ohr}$ & $24 \mathrm{hr}$ \\
\hline アミノレバン & $00 \mathrm{ml}$ & 100 & 67.5 & 38.2 & 27.4 & 8.5 & 無色 & $\leftarrow$ & $\leftarrow$ & $\leftarrow$ & $\leftarrow$ & 6.18 & 5.89 \\
\hline アミパレン* & $0 \mathrm{ml}$ & $100^{*}$ & 3.2 & 0.3 & 0 & & 無色 & 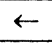 & $\leftarrow$ & $\leftarrow$ & $\leftarrow$ & 7.05 & 6.95 \\
\hline アミュー & $0 \mathrm{ml}$ & 100 & 82.6 & 65.9 & 54.2 & 14.4 & 無色 & & $\leftarrow$ & $\leftarrow$ & 微黄 & 7.31 & 7.22 \\
\hline パンアミン G & $500 \mathrm{ml}$ & 100 & 98.1 & 96.5 & 91.1 & 71.7 & 無色 & & $\leftarrow$ & $\leftarrow$ & $\leftarrow$ & 6.26 & 5.96 \\
\hline プラスアミノ & $200 \mathrm{ml}$ & 100 & 95.9 & 93.1 & 90.9 & 78.1 & 無色 & $\leftarrow$ & $\leftarrow$ & $\leftarrow$ & 微黄 & 5.27 & 5.18 \\
\hline プロテアミン12 & $200 \mathrm{ml}$ & 100 & 6.6 & 77.2 & 64.8 & 26.4 & 無色 & & $\leftarrow$ & $\leftarrow$ & 微黄 & 6.28 & 6.19 \\
\hline マックアミン & $500 \mathrm{ml}$ & 100 & 69.0 & 56.0 & 46.8 & 13.7 & 無色 & $\leftarrow$ & 微黄 & $\leftarrow$ & $\leftarrow$ & 6.96 & 6.84 \\
\hline アミカリック & $500 \mathrm{ml}$ & 100 & 96.6 & 94.0 & 86.9 & 63.0 & 無色 & $\leftarrow$ & 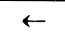 & $\leftarrow$ & 微黄 & 4.77 & 4.74 \\
\hline アミパレンクク 号 & $200 \mathrm{~m}$ & 100 & 94.8 & 83.2 & 70.9 & 45.6 & 無色 & $\leftarrow$ & $\leftarrow$ & $\leftarrow$ & 微黄 & 5.16 & 5.13 \\
\hline アミパレングリ号 & $\begin{array}{l}200 \mathrm{ml} \\
700 \mathrm{ml} \\
\end{array}$ & 100 & 94.8 & 81.5 & 74.1 & 51.2 & 無色 & & & 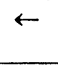 & 微黄 & 5.13 & 5.10 \\
\hline ア゚ミパレンタールA & $\begin{array}{l}200 \mathrm{ml} \\
400 \mathrm{ml}\end{array}$ & 100 & 57.0 & 33.3 & 22.3 & 7.7 & 無色 & - & $\leftarrow$ & $\leftarrow$ & $\leftarrow$ & 6.25 & 6.07 \\
\hline $\begin{array}{l}\text { 12\%イスホポール } \\
\text { トリパレン }\end{array}$ & $\begin{array}{l}200 \mathrm{ml} \\
400 \mathrm{ml}\end{array}$ & 100 & 92.2 & 85.3 & 79.0 & 67.5 & 無色 & 5 & $\leftarrow$ & $\leftarrow$ & $\leftarrow$ & 5.37 & 5.22 \\
\hline $\begin{array}{l}\text { 12\%イスポ゚ール } \\
\text { トリパレン2号 }\end{array}$ & $\begin{array}{l}200 \mathrm{ml} \\
400 \mathrm{ml}\end{array}$ & 100 & 94.9 & 84.3 & 79.3 & 71.2 & 無色 & $\leftarrow$ & $\leftarrow$ & $\leftarrow$ & $\leftarrow$ & 5.54 & 5.37 \\
\hline $\begin{array}{l}\text { プロテアアミン12X } \\
\text { ハイカック号 }\end{array}$ & $\begin{array}{l}200 \mathrm{ml} \\
700 \mathrm{ml}\end{array}$ & 100 & 92.4 & 86.9 & 83.0 & 62.7 & 無色 & $\leftarrow$ & $\leftarrow$ & $\leftarrow$ & $\leftarrow$ & 5.03 & 4.96 \\
\hline プロテアミン12X & $\begin{array}{l}200 \mathrm{ml} \\
700 \mathrm{ml} \\
\end{array}$ & 100 & 79.6 & 71.1 & 68.3 & 51.7 & 無色 & $\leftarrow$ & $\leftarrow$ & $\leftarrow$ & $\leftarrow$ & 5.13 & 5.11 \\
\hline $\begin{array}{l}\text { プロテアミン } 12 X \\
\text { パレメンールA }\end{array}$ & $\begin{array}{l}200 \mathrm{ml} \\
400 \mathrm{ml}\end{array}$ & 100 & 93.8 & 89.0 & 81.8 & 61.6 & 無色 & $\leftarrow$ & $\leftarrow$ & $\leftarrow$ & $\leftarrow$ & 5.82 & 5.78 \\
\hline
\end{tabular}

* 配合後すぐに含量が著しく低下するため、初期濃度は理論值に対し実質100\%ではない。

には炭酸ナトリウムが配合されているため，乳酸 含有輸液との配合時の $\mathrm{pH}$ はメロペネムが安定な 領域にあると考えられる.

d. $3 \%$ 総合アミノ酸製剂

パンアミン $\mathrm{G}$, プラスアミノ中ではメロペネム の残存力価は 6 時間目で $90 \%$ 以上を示したが，同 じ $3 \%$ アミ酸製剤でもグリセリンを含むマック アミン中ではメロペネムは不安定であった。これ は，表 5 に示すよらにグリセオール中でメロペネ ムは著しく不安定なためと考えられる。したがっ て，グリセリンを含まない $3 \%$ アミノ酸製戍とは 配合可能であると考えられる.

e。その他のアミノ酸製剤および高カロリ一輸 液

アミカリック中では 3 時間目で $90 \%$ 以上を示し た。それ以外のアミノ酸製剂の中では不安定であ り，中でもアミパレンでは著しく低い值を示し た. $\beta$-ラクタム抗生物質は水溶液中でアミノ基を 有する化合物と反応することが知られている ${ }^{6)}$.
アミノ酸の絶対量が多いため, メロペネムが不安 定であったと考えられる.

アミノ酸輸液十高カロリ一輸夜の場合, メロペ ネムは不安定であった。 その理由として，高カロ リー輸夜との配合によりアミノ酸含量は低くなる が糖量が多いことが考えられる、アミカリックは 糖量が少ないためメロペネムは比較的安定であっ たと考えられる。

$\mathrm{f}$. 脂肪乳剂

イントラリポス中では, メロペネムの残存力価 は 6 時問目で90\%以上を示し, 性状変化も認めら れなかった。

\section{2. 各種薬剤との配合}

絬果を表 7 〜 10に示す.

(1) 外観

数種の配合で結晶が析出した.メロペネムの生 理食塩液 $100 \mathrm{ml}$ への溶解度は十分であるので, メ ロペネムの析出とは考えられない，特にアドリア シン注，ファルモルビシン注との配合で生じた沈 
表 7. ×ロペネム注射剤 $0.5 \mathrm{~g}$ と薬剤との配合变化 (1)

（生理食塩液 $100 \mathrm{ml}$ 中）

\begin{tabular}{|c|c|c|c|c|c|c|c|c|c|c|c|c|c|}
\hline \multicolumn{2}{|c|}{ 配 合 剂 } & \multicolumn{5}{|c|}{ メロペネム残存力価（\%） } & \multicolumn{5}{|c|}{ 外観 } & \multicolumn{2}{|c|}{$\mathrm{pH}$} \\
\hline \begin{tabular}{|l|l} 
薬剤名 & 酉 \\
\end{tabular} & 配合量 & $\mathrm{Ohr}$ & $1 \mathrm{hr}$ & $3 \mathrm{hr}$ & $6 \mathrm{hr}$ & $24 \mathrm{hr}$ & Ohr & $1 \mathrm{hr}$ & $3 \mathrm{hr}$ & $6 \mathrm{hr}$ & $24 \mathrm{hr}$ & $\mathrm{Ohr}$ & \\
\hline カルバぺ & & \multicolumn{12}{|c|}{ 系抗 生 物 質 } \\
\hline チエナム点滴用 & $500 \mathrm{mg}$ & 100 & 99.7 & 95.8 & 93.2 & 70.3 & & $\leftarrow$ & 炎黄 & & 色 & 70 & \\
\hline \multirow{2}{*}{\multicolumn{4}{|c|}{\begin{tabular}{c|c|c|c|c|c|c|} 
七フェ \\
エポセリン静注用 & $1 \mathrm{~g}$ & 100 & 98.4 & 97.1 & 93.9 & 88.0
\end{tabular}}} & & & & & & & & & & \\
\hline & & & & 97.1 & 93.9 & & & & $\leftarrow$ & & 熿 & 89 & \\
\hline クラフォラン注射用 & $\lg$ & 100 & .5 & .9 & 8 & 6 & 黄 & & & - & 色 & 77 & \\
\hline ケニセフ静注用 & $1 g$ & 100 & 99.3 & & 97.4 & 8 & 黄 & & $\leftarrow$ & & 色 & 92 & \\
\hline コスモシン静注 & $1 \mathrm{~g}$ & 100 & 98.2 & & 96.6 & 3 & & & $\leftarrow$ & & 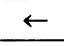 & 81 & \\
\hline 27ア一几静注用 & $1 g$ & 100 & 88.9 & 96.6 & 94.6 & 85.5 & 黄 & & $\leftarrow$ & & 墴 & 64 & \\
\hline マリン静注用 & $1 \mathrm{~g}$ & 100 & & & 92.5 & 5 & & & & & 墴 & 75 & \\
\hline スルペラゾン静注用 & 18 & 100 & 99.0 & & 93.5 & 2 & & & $\leftarrow$ & 炎黄 & 黄色 & 77 & $\underline{5}$ \\
\hline セファメジン注射月 & $1 \mathrm{~g}$ & 100 & 97.8 & 3 & 93.6 & 87.7 & & & & & $\leftarrow$ & .76 & 6 \\
\hline לx注射用 & & 0 & .7 & & 94.5 & .8 & & & e & & & 70 & \\
\hline 外”注射用 & & 100 & 98.3 & & .5 & 1 & 黄 & & & & 淡黄 & 7 & 5 \\
\hline セフメタゾン静注 & $2 g$ & 100 & 99.0 & & .4 & 4 & & & $\leftarrow$ & & $\leftarrow$ & 75 & 4 \\
\hline スリン静注 & 1 & 10 & 9.6 & & 5 & & & & & & & & 3 \\
\hline トミポラン静注用 & 18 & & .5 & & & & & & 淡耳 & & & & \\
\hline ノイセフ静注用 & 10 & 100 & 97.9 & & 95.0 & .8 & 色 & & $\leftarrow$ & & - & 9 & .7 \\
\hline パンスポリン静注 & $1 \mathrm{~g}$ & 10 & .8 & & 0 & & & & $\leftarrow$ & & 黄色 & 0 & .0 \\
\hline マリン静注用 & 18 & & 8.0 & & .6 & & & & & & & 77 & 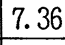 \\
\hline ベススユール静注用 外 & & 10 & 99.5 & & 5.3 & .8 & 黄 & & & & 黄色 & 6 & 1.5 \\
\hline 注射用メイセリン & 10 & 100 & .6 & & 2 & .4 & 黄 & & $\leftarrow$ & & $\leftarrow$ & .57 & .4 \\
\hline モダシン静注用 & $1 \mathrm{~g}$ & 100 & 95.8 & & 95.7 & 88.9 & & & $\leftarrow$ & & 炎黄 & .64 & 7.5 \\
\hline ヤマテタン静注用 & $1 g$ & 100 & 98.1 & .0 & 94.8 & 85.7 & 潢 & & & & 淡黄 & .68 & 7.4. \\
\hline ロセフィン静注用 & $1 \mathrm{~g}$ & 100 & 99.9 & 99.0 & 97.2 & 88.4 & 淡黄 & & $\leftarrow$ & & 黄色 & 7.85 & 7.7 \\
\hline その 他 の & & 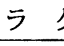 & & 厶豆 & & 生 & 物 質 & & & & & & \\
\hline アザクタム注射用 & 18 & 100 & 99.3 & 97.8 & 97.0 & 88.5 & 微黄 & & $\leftarrow$ & & - & 7.47 & 7.49 \\
\hline アマスリン静注用 & $1 \mathrm{~g}$ & 100 & 99.9 & 99.2 & 97.1 & 86.6 & & & $\leftarrow$ & & 淡黄 & 7.81 & 7.6 \\
\hline ペントリシン注射用 & $4 \mathrm{~g}$ & 100 & 99.3 & 98.9 & 96.0 & 86.9 & & & $\leftarrow$ & & $\leftarrow$ & 7.79 & 7.15 \\
\hline 注射用ペントック不萬有 & $2 \mathrm{~g}$ & 100 & 98.2 & 95.7 & 93.2 & 78.8 & 微黄 & $\leftarrow$ & $\leftarrow$ & $\leftarrow$ & $\leftarrow$ & 8.41 & 8.07 \\
\hline
\end{tabular}

汼は赤色であるため，配合薬剤からの析出である ことは明らかであり，析出した原因としては， メ ロペネム注射剂の配合により溶液の $\mathrm{pH}$ が若干ア ルカリ側へ移行したためと考えられる.

\section{(2) $\mathrm{pH}$}

ほとんどの薬剤において, 配合後の溶液は $\mathrm{pH}$ 7 ～ 8 範囲であったが，点滴静注用ゾビラック ス（pH 約10.4）との配合のみ $\mathrm{pH} 9$ と高い值を 示した. $\mathrm{pH}$ の著しい変動は認められなかったの で, 表 7 １0には配合直後（Oh）と24時間後の值 のみ示した。
(3) 残存力価

配合後 3 時間でメロペネムの残存力価が $90 \%$ 未 満であった配合は，点滴静注用ゾビラックス，イ ノバン注, カタボン注, ネオラミン・スリービー のみであった。

\section{結}

1. 注射用蒸留水, 生理食塩液中では, 容量が $10 \mathrm{ml}$ の垬合でも配合後 6 時間目でメロペネムの 残存力価が $90 \%$ 以上を示した.

2. $5 \%$ ブドゥ糖液の場合, 容量 $100 \mathrm{ml}$ 以上 
表 8. メロペネム注射剂 $0.5 \mathrm{~g}$ と薬剤との配合変化 (2)

（生理食塩夜 $100 \mathrm{ml}$ 中）

\begin{tabular}{|c|c|c|c|c|c|c|c|c|c|c|c|c|c|}
\hline \multicolumn{2}{|c|}{ 配 合 剂 } & \multicolumn{5}{|c|}{ メロペネム残存力価（\%） } & \multicolumn{5}{|c|}{ 外観 } & \multicolumn{2}{|c|}{$\mathrm{pH}$} \\
\hline 薬剤名 & 配合量 & Ohr & $1 \mathrm{hr}$ & $3 \mathrm{hr}$ & $6 \mathrm{hr}$ & $24 \mathrm{hr}$ & Ohr & $1 \mathrm{hr}$ & $3 \mathrm{hr}$ & $6 \mathrm{hr}$ & $24 \mathrm{hr}$ & Ohr & $24 \mathrm{hr}$ \\
\hline \multicolumn{14}{|c|}{ アミノ糖 系抗生物質 } \\
\hline イセパシン注射夜 & $400 \mathrm{mg}$ & 100 & 98.1 & 93.5 & 88.4 & 66.2 & 無色 & $\leftarrow$ & $\leftarrow$ & $\leftarrow$ & 微黄 & 7.16 & 7.09 \\
\hline エクサシン注射液 & $400 \mathrm{mg}$ & 100 & 97.5 & 93.7 & 87.5 & 63.8 & 無色 & $\leftarrow$ & & $\leftarrow$ & 败黄 & 22 & 7.18 \\
\hline ゲンタシン注60 & $120 \mathrm{mg}$ & 100 & 98.9 & 96.1 & 90.7 & 75.3 & 無色 & $\leftarrow$ & & $\leftarrow$ & $\leftarrow$ & .30 & 7.28 \\
\hline トブラシン注 & $90 \mathrm{mg}$ & 100 & 99.3 & 95.4 & 92.0 & 74.9 & 無色 & $\leftarrow$ & & $\leftarrow$ & $\leftarrow$ & .42 & 7.42 \\
\hline パニ难注射液 & $100 \mathrm{mg}$ & 100 & 96.8 & 95.5 & 91.3 & 75.8 & 無色 & $\leftarrow$ & & $\leftarrow$ & $\leftarrow$ & .49 & .46 \\
\hline ハベカシン注射夜 & $100 \mathrm{mg}$ & 100 & 99.6 & 97.3 & 94.3 & 78.3 & 無色 & $\leftarrow$ & & $\leftarrow$ & 微黄 & 7.62 & 7.52 \\
\hline ビクリン注射用 & $200 \mathrm{mg}$ & 100 & 99.2 & 95.8 & 92.2 & 72.2 & 無色 & $\leftarrow$ & & 微黄 & $\leftarrow$ & 7.42 & 7.42 \\
\hline $\begin{array}{l}\text { 硫酸アミカシン } \\
\text { 注射液「萬有」 }\end{array}$ & 100mg & 100 & 99.6 & 96.3 & 91.9 & 71.1 & 無色 & $\leftarrow$ & $\leftarrow$ & $\leftarrow$ & $\leftarrow$ & 7.43 & 7.30 \\
\hline \multicolumn{14}{|c|}{ その他 の 抗生物 質 } \\
\hline アラセナーA & $300 \mathrm{mg}$ & 100 & 98.1 & 96.0 & 96.0 & 88.3 & 微黄 & $\leftarrow$ & $\leftarrow$ & $\leftarrow$ & $\leftarrow$ & 7.58 & 7.65 \\
\hline ジフルか凊争注液0. $2 \%$ & $100 \mathrm{mg}$ & 100 & 98.5 & 97.8 & 92.8 & 85.3 & 微黄 & $\leftarrow$ & & $\leftarrow$ & 黄色 & 7.82 & 7.70 \\
\hline $\begin{array}{l}\text { 点滴静注用ゾビ } \\
\text { ラックス }\end{array}$ & $250 \mathrm{mg}$ & 100 & 93.9 & 85.0 & 73.3 & 48.3 & 微黄 & $\leftarrow$ & $\leftarrow$ & $\leftarrow$ & 淡黄 & 9.32 & 8.58 \\
\hline ダラシンP注 & $600 \mathrm{mg}$ & 100 & 99.2 & 98.0 & 95.4 & 90.7 & 微黄 & $\leftarrow$ & & $\leftarrow$ & 淡黄 & 7.22 & 7.28 \\
\hline フロリードF注 & $400 \mathrm{mg}$ & 100 & 99.0 & 98.2 & 95.1 & 88.4 & 無色 & $\leftarrow$ & 微黄 & 淡黄 & 黄色 & 7.37 & 7.33 \\
\hline 静注用杖ジS & $4 \mathrm{~g}$ & 100 & 99.3 & 96.3 & 93.5 & 86.9 & 微黄 & 6 & & $\leftarrow$ & $\leftarrow$ & 7.48 & 7.48 \\
\hline 点滴静注用ミ/㑇 & $100 \mathrm{mg}$ & 100 & 98.8 & 96.3 & 96.3 & 88.4 & 黄色 & $\leftarrow$ & $\leftarrow$ & $\leftarrow$ & 最黄 & 7.27 & 7.20 \\
\hline \multicolumn{14}{|c|}{ 抗 悪 性 腫 瘍 剂 } \\
\hline アドリアシン注 & $10 \mathrm{mg}$ & 100 & 99.5 & 97.2 & 94.8 & $-\cdots$ & 赤褐 & $\leftarrow$ & $\leftarrow$ & $\leftarrow$ & $\begin{array}{l}\text { 赤色 } \\
\text { 沈激 }\end{array}$ & 7.83 & --- \\
\hline オンコビン & $1 \mathrm{mg}$ & 100 & 96.9 & 95.6 & 94.3 & 87.9 & 微黄 & $\leftarrow$ & $\leftarrow$ & $\leftarrow$ & $\leftarrow$ & 7.81 & 7.78 \\
\hline キロサイド注 & $200 \mathrm{mg}$ & 100 & 99.7 & 96.8 & 94.0 & 85.1 & 微黄 & & & $\leftarrow$ & $\leftarrow$ & 7.84 & 7.74 \\
\hline 注射用デラルビジ & $20 \mathrm{mg}$ & 100 & 99.1 & 95.4 & 94.1 & & 赤褐 & 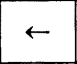 & $\leftarrow$ & $\leftarrow$ & $\begin{array}{l}\text { 赤色 } \\
\text { 沈港 }\end{array}$ & 7.89 & \\
\hline パラプラチ注射夜 & $450 \mathrm{mg}$ & 100 & 99.5 & 98.9 & 98.2 & 84.2 & 無色 & 微黄 & & & $\leftarrow$ & 7.81 & 7.72 \\
\hline ピシバニール5KE & $5 \mathrm{KE}$ & 100 & 99.6 & 97.2 & 94.7 & 89.6 & 微黄 & $\leftarrow$ & $\leftarrow$ & $\leftarrow$ & $\leftarrow$ & 7.83 & 7.79 \\
\hline ファルモルビシン注 & $10 \mathrm{mg}$ & 100 & 99.3 & 98.5 & 96.2 & --- & 赤褐 & $\leftarrow$ & $\leftarrow$ & $\leftarrow$ & $\begin{array}{l}\text { 赤色 } \\
\text { 沈澱 }\end{array}$ & 7.83 & --- \\
\hline 注射用7价デジ & $3 \mathrm{mg}$ & 100 & 96.9 & 94.6 & 94.1 & 84.8 & 微黄 & $\leftarrow$ & $\leftarrow$ & $\leftarrow$ & $\leftarrow$ & 7.84 & 7.71 \\
\hline 又仆又隹協和S & $10 \mathrm{mg}$ & 100 & 96.6 & 95.2 & 93.7 & 86.6 & 薄紫 & $\leftarrow$ & $\leftarrow$ & $\leftarrow$ & $\leftarrow$ & 7.85 & 7.73 \\
\hline 注射用水性一个 & $50 \mathrm{mg}$ & 100 & 97.1 & 93.2 & 92.5 & 85.6 & 黄色 & $\leftarrow$ & & $\leftarrow$ & $\leftarrow$ & 7.85 & 7.79 \\
\hline ラステット注 & $100 \mathrm{mg}$ & 100 & 100 & --- & --- & --- & 微黄 & $\leftarrow$ & $\begin{array}{l}\text { 白色 } \\
\text { 沈澱 }\end{array}$ & --- & --- & 7.65 & -- \\
\hline ランダ注 & $50 \mathrm{mg}$ & 100 & 98.1 & 96.4 & 93.2 & 87.0 & 無色 & 微黄 & & 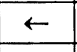 & $\leftarrow$ & 7.81 & 7.73 \\
\hline Vチ手け〈山之内〉 & $1 \mathrm{mg}$ & 100 & 99.5 & 95.9 & 94.1 & 86.6 & 微黄 & $\leftarrow$ & $\leftarrow$ & $\leftarrow$ & $\leftarrow$ & 7.80 & 7.80 \\
\hline
\end{tabular}

であれば配合後 3 時間目でメロペネムの残存力洒 が90\%以上を示した。 また，糖濃度が高くなるほ どメロペネムは不安定であった.

3. 維持液およびリンゲル液との配合では 3 時 間目でメロペネム残存力価はほぼ $90 \%$ 以上を示 し，実用上配合に問題ないと考えられた.

4. グリセリンを含まない $3 \%$ 総合アミノ酸製
剂との配合は良好で， 6 時間目でメロペネムの残 存力価が $90 \%$ 以上を示した.

5. アミカリックとの配合では 3 時間目でメロ ペネムの残存力価が90\%以上を示したが，10\%, $12 \%$ 総合アミノ酸製剂十高カロリー輸夜との配合 では不安定であった。

6. 脂肪乳剤中で配合後 6 時間目でメロペネム 
表 9. メロペネム注射剂 $0.5 \mathrm{~g}$ と薬剤との配合変化 (3)

（生理食塩液 100ml 中）

\begin{tabular}{|c|c|c|c|c|c|c|c|c|c|c|c|c|c|}
\hline 配 & & & & & & & & & 外観 & & & & $\mathrm{H}$ \\
\hline 薬剤名 & 配合量 & Ohr & $1 \mathrm{hr}$ & $3 \mathrm{hr}$ & $6 \mathrm{hr}$ & $24 \mathrm{hr}$ & $\mathrm{Ohr}$ & $1 \mathrm{hr}$ & $3 \mathrm{hr}$ & $6 \mathrm{hr}$ & $24 \mathrm{hr}$ & Ohr & $24 \mathrm{hr}$ \\
\hline 血液系用 & 剂 & & & & & & & & & & & & \\
\hline $\begin{array}{l}\text { アドナ(AC-17) } \\
\text { 注射液(静脈用) }\end{array}$ & 100mg & 100 & 98.9 & 96.7 & 93.5 & 86.3 & 橙色 & $\leftarrow$ & $\leftarrow$ & $\leftarrow$ & $\leftarrow$ & 7.66 & 7.62 \\
\hline 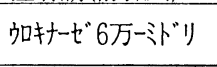 & $\begin{array}{l}\text { 6万国 } \\
\text { 際単位 }\end{array}$ & 100 & 99.8 & 95.8 & 93.6 & 87.3 & 無色 & $\leftarrow$ & $\leftarrow$ & 微黄 & $\leftarrow$ & 7.83 & 7.77 \\
\hline エポジン注3000 & $\begin{array}{l}\text { 3000国 } \\
\text { 際単位 }\end{array}$ & 100 & 100 & 98.2 & 97.0 & 88.7 & 無色 & $\leftarrow$ & 微黄 & $\leftarrow$ & $\leftarrow$ & 7.89 & 7.68 \\
\hline トランサミンS注 & $1 \mathrm{~g}$ & 100 & 98.5 & 96.2 & 94.6 & 81.0 & 無色 & $\leftarrow$ & 微黄 & $\leftarrow$ & 淡黄 & 7.84 & 7.78 \\
\hline $\begin{array}{l}\text { ペリンナトリウ } \\
\text { ム注N「シミズ」 }\end{array}$ & $\begin{array}{l}5000 \\
\text { 単位 }\end{array}$ & 100 & 97.8 & 94.2 & 92. 9 & 85.8 & 無色 & $\leftarrow$ & $\leftarrow$ & 微黄 & $\leftarrow$ & 7.92 & 7.76 \\
\hline 循 環 器 用 & 剂 & & & & & & & & & & & & \\
\hline イノバン注 & $100 \mathrm{mg}$ & 100 & 94.4 & 82.6 & 72.9 & 44.7 & 無色 & $\leftarrow$ & $\leftarrow$ & $\leftarrow$ & $\leftarrow$ & 7.79 & 7.62 \\
\hline カタボン注 & $100 \mathrm{mg}$ & 100 & 96.6 & 87.0 & 8.4 & 52.8 & 無色 & $\leftarrow$ & $\leftarrow$ & $\leftarrow$ & $\leftarrow$ & 7.55 & 7.52 \\
\hline ソルダクトン & $200 \mathrm{mg}$ & 100 & 97.8 & 95.1 & 94.3 & 84.4 & 微黄 & $\leftarrow$ & $\leftarrow$ & $\leftarrow$ & 淡黄 & 7.96 & 7.85 \\
\hline ドブトレックス注射液 & $100 \mathrm{mg}$ & 100 & 96.9 & 90.2 & 84.8 & 63.2 & 無色 & $\leftarrow$ & 微黄 & $\leftarrow$ & $\leftarrow$ & 7.82 & 7.73 \\
\hline ニコリン注射液 & $500 \mathrm{mg}$ & 100 & 98.9 & 95.9 & 92.6 & 80.0 & 無色 & $\leftarrow$ & 微黄 & $\leftarrow$ & $\leftarrow$ & 7.89 & 7.85 \\
\hline ニトロール注 & $5 \mathrm{mg}$ & 100 & 98.9 & 96.9 & 95.4 & 87.8 & 無色 & $\leftarrow$ & 微黄 & $\leftarrow$ & $\leftarrow$ & 7.85 & 7.82 \\
\hline ノバスタン注 & $10 \mathrm{mg}$ & 100 & 98.6 & 95.4 & 91.5 & 77.6 & 微黄 & $\leftarrow$ & $\leftarrow$ & $\leftarrow$ & 淡黄 & 7.81 & 7.76 \\
\hline パルクス注 & $10 \mu \mathrm{g}$ & 100 & 95.4 & 93.6 & 92.9 & 85.3 & $* 1$ & $\leftarrow$ & $\leftarrow$ & $\leftarrow$ & $\leftarrow$ & 7.90 & 7.80 \\
\hline 注射用プロス夘デイ & $500 \mu \mathrm{g}$ & 100 & 98.5 & 96.1 & 93.6 & 86.6 & 微黄 & $\leftarrow$ & $\leftarrow$ & $\leftarrow$ & $\leftarrow$ & 7.81 & 7.80 \\
\hline ペルジピ注射液 & $10 \mathrm{mg}$ & 100 & -- & ---- & --- & ---- & 白濁 & --- & --- & --- & --- & --- & --- \\
\hline ルベッサー注射用50 & $50 \mathrm{mg}$ & 100 & 98.8 & 96.6 & 93.5 & 85.7 & 微黄 & $\leftarrow$ & $\leftarrow$ & $\leftarrow$ & $\leftarrow$ & 7.80 & 7.73 \\
\hline ミリスロール注 & $50 \mathrm{mg}$ & 100 & 98.2 & 93.1 & 85.1 & 60.3 & 無色 & 微黄 & $\leftarrow$ & $\leftarrow$ & 淡黄 & 7.94 & 7.91 \\
\hline ラシックス100mg注 & $100 \mathrm{mg}$ & 100 & 97.9 & 96.4 & 92.6 & 86.0 & 微黄 & $\leftarrow$ & $\leftarrow$ & $\leftarrow$ & $\leftarrow$ & 7.86 & 7.78 \\
\hline 注射用ルトドリール & $250 \mathrm{mg}$ & 100 & 99.6 & 96.6 & 95.3 & 91.2 & 微黄 & $\leftarrow$ & $\leftarrow$ & $\leftarrow$ & $\leftarrow$ & 7.26 & 7.08 \\
\hline ビタミン & & & & & & & & & & & & & \\
\hline $\begin{array}{l}\text { Pスבルビ唒夋注射液 } \\
\text { ビタシンC注「フリー」 }\end{array}$ & $500 \mathrm{mg}$ & 100 & 99.1 & 94.9 & 95.3 & 81.3 & 無色 & $\leftarrow$ & $\leftarrow$ & $\leftarrow$ & $\leftarrow$ & 7.75 & 7.58 \\
\hline M. V. I注〔工巩入] & $5 \mathrm{ml}$ & 100 & 99.1 & 93.0 & 89.8 & 76.1 & 黄色 & $\leftarrow$ & $\leftarrow$ & $\leftarrow$ & $\leftarrow$ & 6.87 & 6.90 \\
\hline 邓ラーゼ「杏林」50mg & $50 \mathrm{mg}$ & 100 & 99.4 & 96.3 & 95.3 & 88.3 & 無色 & $\leftarrow$ & $\leftarrow$ & $\leftarrow$ & $\leftarrow$ & 7.61 & 7.32 \\
\hline $\begin{array}{l}\text { 祆ラシン・列-ビー液 } \\
\text { (静注用) }\end{array}$ & $10 \mathrm{ml}$ & 100 & 96.8 & 89.2 & 85.6 & 74.7 & 微赤 & $\leftarrow$ & $\leftarrow$ & $\leftarrow$ & 黄色 & 6.94 & 6.80 \\
\hline $\begin{array}{l}\text { 静注用ビタノイリ } \\
\text { ン「タケダ」 }\end{array}$ & $1 ハ ゙$ 仍 & 100 & 100 & 93.7 & 89.7 & 67.8 & 黄色 & $\leftarrow$ & $\leftarrow$ & 橙色 & 赤色 & 7.27 & 6.98 \\
\hline ビタメジ凊註用 & $1 ハ ゙$ 仍 & 100 & 93.7 & 90.9 & 88.8 & 80.9 & 微赤 & $\leftarrow$ & $\leftarrow$ & $\leftarrow$ & $\leftarrow$ & 7.01 & 6.94 \\
\hline フラビタン注射液 & $20 \mathrm{mg}$ & 100 & 99.1 & 97.3 & 94.6 & 87.1 & 黄色 & $\leftarrow$ & $\leftarrow$ & $\leftarrow$ & $\leftarrow$ & 7.83 & 7.71 \\
\hline 好バール注射液 & $500 \mu \mathrm{g}$ & 100 & 99.2 & 96.3 & 93.9 & 86.9 & 微赤 & $\leftarrow$ & $\leftarrow$ & $\leftarrow$ & 微橙 & 7.84 & 7.82 \\
\hline 祆ラシ・ママルチV & $10 \mathrm{ml}$ & 100 & 97.0 & 95.7 & 90.5 & 81.8 & 黄色 & $\leftarrow$ & $\leftarrow$ & $\leftarrow$ & $\leftarrow$ & 7.53 & 7.38 \\
\hline
\end{tabular}
* 1 : 配合前と変わらず

の残存力価が $90 \%$ 以上を示した。

7. 各種薬剂との配合性においても 3 時間目で メロペネムの残存力価はほぼ90\%以上を示し，実 用上配合に問題ないと考兄られた。

以上のように, メロペネム注射剂と各種輸液・ 薬剤との配合性が確認され，臨床の埸での適切な
配合方法が確立された.

謝辞 本研究にあたり，有益な御助言を賜りました 住友製薬総合研究所, 砂川洵博士に深く感謝いたしま す.

\section{引用文 献}

1) M. Sunagawa, H. Matsumura, T. Inoue, M. 
表 10. メロペネム注射剤 $0.5 \mathrm{~g}$ と薬㶡との配合変化 (4)

（生理食塩液 $100 \mathrm{ml}$ 中）

\begin{tabular}{|c|c|c|c|c|c|c|c|c|c|c|c|c|c|}
\hline 配 & & & & & & & & & & & & & \\
\hline 薬剂名 & 配合量 & $\mathrm{Ohr}$ & $1 \mathrm{hr}$ & $3 \mathrm{hr}$ & $6 \mathrm{hr}$ & $24 \mathrm{hr}$ & Ohr & $1 \mathrm{hr}$ & $3 \mathrm{hr}$ & $6 \mathrm{hr}$ & 4hr & $\mathrm{Ohr}$ & $24 \mathrm{hr}$ \\
\hline 消 化器 矛 & & & & & & & & & & & & & \\
\hline ゙゙スター注射用 & $20 \mathrm{mg}$ & 100 & 99.9 & 97.2 & 95.5 & 8.4 & 無色 & $\leftarrow$ & & & $\leftarrow$ & .78 & \\
\hline "ジンUコーワ注400 & Omg & & & & & & & & & & 黄 & 30 & 27 \\
\hline ザンタック注射液 & $50 \mathrm{mg}$ & 100 & 6 & 97.3 & 94.2 & 35.4 & 收黄 & $\leftarrow$ & & & $\leftarrow$ & .79 & 7.79 \\
\hline ソルコセリル「注」 & $4 \mathrm{ml}$ & 100 & .9 & 36.4 & 96.0 & 36.8 & 敞黄 & $\leftarrow$ & & & & .91 & .85 \\
\hline タガメット注射液 & $200 \mathrm{mg}$ & 100 & .2 & 7.3 & 96.2 & 88.9 & 無色 & 敉黄 & & & & .32 & .41 \\
\hline M゚ラ注射液 & $10 \mathrm{mg}$ & 100 & 98.6 & 6.9 & 6.4 & 5.7 & 無色 & & & & & 7.82 & 7.82 \\
\hline 副 腎 皮 質 & ル & モ & 剂 & & & & & & & & & & \\
\hline "゙がロさS注射腋 & $100 \mathrm{mg}$ & 100 & 98.8 & 97.1 & 95.6 & 87.2 & 微黄 & $\leftarrow$ & & 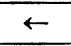 & $\leftarrow$ & 7.96 & 7.89 \\
\hline 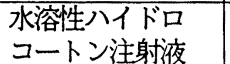 & $500 \mathrm{mg}$ & 100 & 99.4 & 99.2 & 97.6 & 85.6 & 無色 & $\leftarrow$ & $\leftarrow$ & $\leftarrow$ & $\leftarrow$ & 7.95 & 7.88 \\
\hline 水溶性プレドニン & $50 \mathrm{mg}$ & 100 & 93.2 & 90.8 & 87.4 & 80.4 & 微黄 & 6 & & & 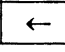 & 7.74 & 7.69 \\
\hline 代謝 系 用 & & & & & & & & & & & & & \\
\hline 际゙极-Lコ-ワ注4号 & $40 \mathrm{mg}$ & 100 & 98.9 & 96.4 & 95.0 & 86.5 & 微黄 & $\leftarrow$ & $\leftarrow$ & $\leftarrow$ & $\leftarrow$ & 7.95 & 7.88 \\
\hline 注射用エフオーワ1500 & $0 \mathrm{mg}$ & 100 & -- & -- & --- & - & 白濁 & --- & -- & $\cdots$ & - & - & --- \\
\hline 注射用フサン50 & Omg & 100 & 99.8 & 96.0 & 94.6 & 85.2 & 無色 & $\leftarrow$ & & 微黄 & 淡黄 & 7.81 & 7.72 \\
\hline ミラクリッド & & 100 & 98.7 & 96.0 & 95.7 & 86.0 & 無色 & 微黄 & $\leftarrow$ & $\leftarrow$ & $\leftarrow$ & 7.87 & 7.83 \\
\hline 血漿分画 & 製 剂 & & & & & & & & & & & & \\
\hline ヴェグロブリーI & $2.5 \mathrm{~g}$ & 100 & 95.9 & 93.4 & 90.1 & 75.2 & 微黄 & $\leftarrow$ & & $\leftarrow$ & $\leftarrow$ & 7.63 & 7.76 \\
\hline ヴェグロブリー-IH & $2.5 \mathrm{~g}$ & 100 & 95.9 & 92.4 & 90.7 & 66.7 & 微黄 & & & 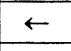 & 黄色 & 7.60 & 7.66 \\
\hline ガンマ・ベニンP & $2.5 \mathrm{~g}$ & 100 & 96.3 & 90.3 & 81.5 & 50.3 & 微黄 & & & 淡黄 & 黄色 & 7.65 & 7.32 \\
\hline ベニロン & $2.5 \mathrm{~g}$ & 100 & 95.2 & 90.2 & 79.6 & 47.5 & & & & $\leftarrow$ & 左色 & .52 & 7.37 \\
\hline ポリグロビンN. & $2.5 \mathrm{~g}$ & 100 & 94.6 & 91.0 & 88.2 & 63.1 & 微黄 & $\leftarrow$ & & & 黄褐 & 7.14 & 7.09 \\
\hline そ の 他 & & & & & & & & & & & & & \\
\hline アスパラK注射夜 & $10 \mathrm{ml}$ & 100 & 99.4 & 99.4 & 97.0 & 85.9 & 無色 & $\leftarrow$ & & 僙 & 淡黄 & 7.71 & 7.73 \\
\hline アデラビン9号 & $2 \mathrm{ml}$ & 100 & 98.1 & 98.5 & 95.6 & 83.3 & 黄色 & $\leftarrow$ & $\leftarrow$ & $\leftarrow$ & $\leftarrow$ & 7.87 & 7.80 \\
\hline 点滴用扭测代 $10 \%$ & $10 \mathrm{ml}$ & 100 & 98.5 & 95.5 & 93.8 & 89.4 & 無色 & $\leftarrow$ & $\leftarrow$ & 微黄 & $\leftarrow$ & 7.29 & 7.26 \\
\hline ザルソカイン & $10 \mathrm{ml}$ & 100 & 82.6 & 76.4 & 74.7 & 66.6 & 無色 & & & $\leftarrow$ & $\leftarrow$ & 7.63 & 7.54 \\
\hline ソセゴン注射液 & $30 \mathrm{mg}$ & 100 & 99.7 & 98.7 & 95.1 & 83.2 & 無色 & & & 4 & 5 & 7.77 & 7.75 \\
\hline ネオファーゲンC注 & $20 \mathrm{ml}$ & 100 & 97.7 & 94.4 & 90.2 & 77.3 & 無巴巴 & 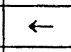 & $\leftarrow$ & $\leftarrow$ & $\leftarrow$ & 7.65 & 7.64 \\
\hline $\begin{array}{l}\text { ヒルトニン2mg } \\
\text { 注射夜「タケダ」 }\end{array}$ & $2 \mathrm{mg}$ & 100 & 96.5 & 94.0 & 92.4 & 83.9 & 無色 & $\leftarrow$ & $\leftarrow$ & 微黄 & $\leftarrow$ & 7.90 & 7.78 \\
\hline
\end{tabular}

Fukasawa and M. Kato, J. Antibiotics, 43, 519-532 (1990).

2) 石丸末明, 井上公雄, 坂口 孝, 化学療法の領 域, 5, 1334-1342 (1989).

3) Y.Takeuchi, Y.Takebayasi, M. Sunagawa, Y. Isobe, Y.Hamazume, A. Uemura and T.Noguchi, Chem. Pharm. Bull., 41, 1998-2002
(1993).

4) H. Bundgaard and C.Larsen, Int. J. Pharm., 16, 319-325 (1983).

5) T. Yamana and A.Tsuji, J. of Pharm. Sci., 65, 1563-1573 (1976).

6) 山名月中, 水上勇三, 市村藤雄, 横川弘一, 薬威 学, 38, 234-237 (1978). 